\title{
Medicinal mushrooms as an attractive new source of natural compounds for future cancer therapy
}

\author{
Artem Blagodatski ${ }^{1,2, *}$, Margarita Yatsunskaya ${ }^{3, *}$, Valeriia Mikhailova ${ }^{1}$, Vladlena \\ Tiasto $^{1}$, Alexander Kagansky ${ }^{1}$ and Vladimir L. Katanaev ${ }^{1,2}$ \\ ${ }^{1}$ Centre for Genomic and Regenerative Medicine, School of Biomedicine, Far Eastern Federal University, Vladivostok, Russian \\ Federation \\ ${ }^{2}$ Department of Pharmacology and Toxicology, University of Lausanne, Lausanne, Switzerland \\ ${ }^{3}$ Federal Scientific Center of the East Asia Terrestrial Biodiversity FEB RAS, Vladivostok, Russia \\ *These authors have contributed equally to this work \\ Correspondence to: Alexander Kagansky, email: kagasha@yahoo.com \\ Vladimir L. Katanaev, email: vladimir.katanaev@unil.ch \\ Keywords: cancer; fungotherapy; medicinal mushrooms; targeted treatment; biomedicine \\ Received: April 11,2018 Accepted: June 04, $2018 \quad$ Published: June 26, 2018 \\ Copyright: Blagodatski et al. This is an open-access article distributed under the terms of the Creative Commons Attribution License \\ 3.0 (CC BY 3.0), which permits unrestricted use, distribution, and reproduction in any medium, provided the original author and \\ source are credited.
}

\section{ABSTRACT}

Medicinal mushrooms have been used throughout the history of mankind for treatment of various diseases including cancer. Nowadays they have been intensively studied in order to reveal the chemical nature and mechanisms of action of their biomedical capacity. Targeted treatment of cancer, non-harmful for healthy tissues, has become a desired goal in recent decades and compounds of fungal origin provide a vast reservoir of potential innovational drugs. Here, on example of four mushrooms common for use in Asian and Far Eastern folk medicine we demonstrate the complex and multilevel nature of their anticancer potential, basing upon different groups of compounds that can simultaneously target diverse biological processes relevant for cancer treatment, focusing on targeted approaches specific to malignant tissues. We show that some aspects of fungotherapy of tumors are studied relatively well, while others are still waiting to be fully unraveled. We also pay attention to the cancer types that are especially susceptible to the fungal treatments.

\section{INTRODUCTION}

Nature has since long been an important source of inspiration for the medicine. Throughout evolution, nature produces a vast diversity of biologically active substances, which possess enormous therapeutic potential, amongst other things regarding the treatment of cancers. Natural products have already yielded a series of compounds widely used in anticancer chemotherapy, whilst application of such products in folk and traditional medicine has always been an important clue pointing to potential new sources of compounds with therapeutic potential. Wellknown examples include camptothecin derived from the bark and stem of the tree Camptotheca acuminata used in Chinese traditional medicine [1], vinca alcaloids derived from Madagascan periwinkle [2] or taxanes derived from the Pacific Yew [3]. Nevertheless, such "first-generation" natural chemotherapeutic agents are directed mostly against housekeeping processes (such as DNA replication or microtubule polymerization and stabilization), which are more active against fast proliferating cancer cells, but are in no way cancer-specific. This results in a variety of harmful side effects in the conventional anticancer chemotherapy, up to eventual patient's death due to overdose. More up-to-date approaches to cancer treatment involve targeted therapies specific to the hallmarks of cancer and harmless or of low harm to the healthy tissues [4]. Search for compounds able to selectively act on cancer cells or on tumorigenic processes is therefore a problem of the highest priority in the field. Thus, it is a task of great importance to "mine the treasury" of natural products for such compounds in order to expand the arsenal of modern oncology with a variety of highly specific tools. 
Cancer fungotherapy is a promising scientific field, which deals with antitumor substances derived from mushrooms. It has been an integral part of the world traditional medicine since the antiquity [5].

The concept of fungal treatment officially appeared in Traditional Chinese Medicine and can be dated back to several thousand years ago [6]. The ancient Chinese pharmacopoeia included hundreds of herbal and fungal species - the latter were considered to be the most effective natural remedies for various types of tumors [6]. In other countries of East and Southeast Asia, mushrooms were also highly valued and rated as "beneficial to health" for centuries. Plant and fungal products were also widespread in Russia, representing the main medicinal resources until the $18^{\text {th }}$ century [7].

In the middle of the $20^{\text {th }}$ century, some of the earliest scientific research was performed on Boletus edulis in order to study the antitumor activity of edible and medicinal mushrooms [8].

Over the past 60 years, the rate of studies focusing on fungi increased exponentially, but in many areas of research mushrooms as potential source for beneficial products are still ignored. For instance, 90\% of fungal species were never analyzed with respect to their antibiotic and antitumor activity. Moreover, a large part of cancerrelated investigations done on fungi deals merely with characterization of unspecific cytotoxic or cytostatic effects on cancer cells (such effects would be harmful for healthy cells as well), rather than with modulation of specific oncogenic signaling pathways, which could be targets for modern, highly specific anticancer therapies. Importantly, a tumor has many "weak spots" and can be targeted at different levels, such as tumor-specific proproliferation signaling, regulation of apoptosis, cancerspecific metabolism, angiogenesis, metastasis and, last but not least, modulation of the immune system. The peculiarity of medicinal mushrooms is that, being producers of hundreds of compounds, they can affect multiple cancer-related processes in synergistic ways when used as a treatment. Thus, not only studies of certain fungal-derived compounds are important, but also research on complex anticancer effects caused by the combinations of molecules in their extracts is of a high interest.

In this review, we intend to analyze the recent knowledge, potential to cover the abovementioned processes on the example of four Basidiomycota mushrooms: Fomitopsis pinicola, Hericium erinaceus, Trametes versicolor and Inonotus obliquus. The fields of cancer fungotherapy and of search for novel antitumor agents are by far not limited to these species; however, these four can serve as typical representatives of widespread medicinal mushrooms used both in traditional medicine and in modern biomedical research. They belong to three different orders, and are a rich source of bioactive compounds such as polyphenols, polysaccharides, glucans, terpenoids, steroids, cerebrosides and proteins, which can be used for treatment of various cancers (Table $1)$. We chose these representatives to convexly illustrate the therapeutic potential of the fungi and fungal-derived products in relation to cancer and to inspire further interdisciplinary work at the junction of oncology and mycology, which should result in future discoveries of novel low-toxic drugs with highly specific antitumor activities.

\section{Fomitopsis pinicola}

Fomitopsis pinicola, class Agaricomycetes, order Polyporales, family Fomitopsidaceae (common name Red Belted Conk) (Figure 1), is a brown rot fungus, a member of Basidiomycota. It is saprotrophic on the dead wood of coniferous and broad-leaved trees, which are common throughout the temperate Northern Hemisphere. [9].

$F$. pinicola fruiting bodies, which are considered to be nontoxic mushrooms in Europe [10], have been used in Korean folk medicine as hemostatic and anti-inflammation agents $[10,11]$. F. pinicola is known to contain a variety of primary metabolites (such as polysaccharides) and secondary metabolites (such as triterpenes, esters, lactones and steroids) $[12,13]$. Extracts and isolated compounds from $F$. pinicola have demonstrated various biological activities, including antioxidant [14-16], antimicrobial [10], anti-inflammatory [17], and cytotoxic [18, 19]. Regarding the antitumor potential of $F$. pinicola, there is not much data present, but a few existing studies motivate to expand the research in this direction. Indeed, a nonspecific cytotoxic activity on human cancer cells such as HeLa and hepatocarcinoma lines SNU 185 and SNU 354 has been shown for the methanol but not for water extracts of F. pinicola [16].

Recently, more studies have been performed on $F$. pinicola extracts in a search for more specific anticancer activity. Chlorophorm extracts of the mushroom have demonstrated cytotoxicity, which was almost twice more specific to colorectal cancer cells (SW-480) than to control HEK293 cells. The cytotoxic effect took place through the ROS-mediated apoptotic mechanism. Moreover, the extracts were able to inhibit migration of the SW-480 cells in scratch wound and transwell assays by means of downregulation of matrix metalloproteinases [20]. The authors claim that one (but not the only) of the acting compounds of the mushroom is ergosterol, for it was one of the major components of the extracts and could produce similar, although slighter effects on SW-480 cells [20]. Another study has revealed the potential of $F$. pinicola ethanol extracts not only to induce apoptosis in various human and murine cancer cell lines, but also to significantly inhibit xenograft sarcoma-derived tumor growth in mice, along with prolongation of their survival time and absence of severe side effects, when given as a food supplement [21]. Interestingly, combined treatment of mice with the extract and a common chemotherapeutic 
Table 1: The metabolites found in medicinal mushrooms and their therapeutic potential against cancer

\begin{tabular}{|c|c|c|c|c|c|}
\hline Species & Compound/derivative & $\begin{array}{c}\text { Targets/mechanisms of } \\
\text { action }\end{array}$ & $\begin{array}{l}\text { Cancer types } \\
\text { affected }\end{array}$ & $\begin{array}{c}\text { Experimental } \\
\text { models }\end{array}$ & References \\
\hline \multirow[t]{5}{*}{$\begin{array}{l}\text { Fomitopsis } \\
\text { pinicola }\end{array}$} & Methanol extract & Cytotoxicity & $\begin{array}{l}\text { Hepatocarcinoma, } \\
\text { cervical cancer }\end{array}$ & Cell lines & [16] \\
\hline & Chlorophorm extract & ROS-mediated apoptosis & Colorectal cancer & Cell lines & {$[20]$} \\
\hline & & $\begin{array}{c}\text { Metalloproteinase- } \\
\text { mediated migration } \\
\text { inhibition }\end{array}$ & Colorectal cancer & Cell lines & {$[20]$} \\
\hline & Ergosterol & ROS-mediated apoptosis & Colorectal cancer & Cell lines & {$[20]$} \\
\hline & Ethanol extract & Tumor growth arrest & Sarcoma & $\begin{array}{l}\text { Mouse } \\
\text { xenograft } \\
\text { tumors }\end{array}$ & {$[21]$} \\
\hline \multirow[t]{12}{*}{$\begin{array}{l}\text { Hericium } \\
\text { erinaceus }\end{array}$} & Ethanol extract & Tumor growth arrest & $\begin{array}{l}\text { Gastric, liver, } \\
\text { colon cancer }\end{array}$ & $\begin{array}{l}\text { Cell lines, } \\
\text { Mouse } \\
\text { xenograft } \\
\text { tumors }\end{array}$ & [29] \\
\hline & Water extract & $\begin{array}{c}\text { Metalloproteinase- } \\
\text { mediated migration } \\
\text { inhibition, suppression } \\
\text { of ERK and JNK kinase } \\
\text { activation }\end{array}$ & Colon carcinoma & $\begin{array}{l}\text { Mouse } \\
\text { xenograft } \\
\text { tumors }\end{array}$ & {$[30]$} \\
\hline & & $\begin{array}{c}\text { NK cells and } \\
\text { macrophages } \\
\text { stimulation, arrest of } \\
\text { angiogenesis }\end{array}$ & Colon carcinoma & $\begin{array}{l}\text { Mouse } \\
\text { xenograft } \\
\text { tumors }\end{array}$ & {$[30]$} \\
\hline & & $\begin{array}{c}\text { Apoptosis via } \\
\text { downregulation of } \\
\text { antiapoptotic proteins }\end{array}$ & Leukemia & Cell lines & {$[31]$} \\
\hline & Polysaccharides & Immunostimulation, & - & Mouse models & {$[32-34]$} \\
\hline & Erinacine A (ditherpenoid) & $\begin{array}{c}\text { ROS-mediated cell cycle } \\
\text { arrest }\end{array}$ & $\begin{array}{l}\text { Gastrointestinal } \\
\text { cancer, colorectal } \\
\text { cancer }\end{array}$ & $\begin{array}{l}\text { Cell lines, } \\
\text { Mouse } \\
\text { xenograft } \\
\text { tumors }\end{array}$ & {$[35-37]$} \\
\hline & & Antiinvasive & & & \\
\hline & Cerebroside E & Angiogenesis blocker & - & $\begin{array}{l}\text { HUVEC cell } \\
\text { line }\end{array}$ & {$[38]$} \\
\hline & HEP3 protein & $\begin{array}{l}\text { Immunostimulation via } \\
\text { gut microbiota }\end{array}$ & Adenocarcinoma & $\begin{array}{l}\text { Mouse } \\
\text { xenograft } \\
\text { tumors }\end{array}$ & [39] \\
\hline & HEG-5 glycoprotein & Proapoptotic stimulation & Gastric cancer & Cell lines & {$[40]$} \\
\hline & Ethanol extract & Cytoprotective & $\begin{array}{l}\text { Gastric ulcer } \\
\text { (carcinogenic } \\
\text { condition) }\end{array}$ & Rat model & [42] \\
\hline & $\begin{array}{l}\text { 1-(5-chloro-2- } \\
\text { hydroxyphenyl)-3- } \\
\text { methyl-1-butanone,2,5- } \\
\text { bis(methoxycarbonyl) } \\
\text { terephthalic acid }\end{array}$ & $\begin{array}{l}\text { Helicobacter Pylori } \\
\text { growth inhibition }\end{array}$ & $\begin{array}{l}\text { Gastric ulcer } \\
\text { (carcinogenic } \\
\text { condition) }\end{array}$ & $\begin{array}{c}\text { In vitro } \\
\text { bacterial } \\
\text { growth models }\end{array}$ & [43] \\
\hline \multirow[t]{2}{*}{$\begin{array}{l}\text { Inonotus } \\
\text { obliquus }\end{array}$} & Water extracts & Cytotoxic/cytostatic & $\begin{array}{l}\text { Colon cancer, } \\
\text { liver cancer }\end{array}$ & Cell lines & {$[52-54]$} \\
\hline & & & & & (continued) \\
\hline
\end{tabular}




\begin{tabular}{|c|c|c|c|c|c|}
\hline Species & Compound/derivative & $\begin{array}{c}\text { Targets/mechanisms of } \\
\text { action }\end{array}$ & $\begin{array}{l}\text { Cancer types } \\
\text { affected }\end{array}$ & $\begin{array}{l}\text { Experimental } \\
\text { models }\end{array}$ & References \\
\hline & & Tumor growth inhibition & Melanoma & $\begin{array}{l}\text { Mouse } \\
\text { xenograft } \\
\text { tumors }\end{array}$ & [55] \\
\hline & & & Sarcoma & & [56] \\
\hline & $\begin{array}{l}\text { Inonotodiol and } \\
\text { inonotsuoxides (lanostan- } \\
\text { type triterpenoids) }\end{array}$ & Tumor growth inhibition & $\begin{array}{l}\text { Skin cancer, } \\
\text { leukemia }\end{array}$ & $\begin{array}{l}\text { Mouse } \\
\text { xenograft } \\
\text { tumors }\end{array}$ & {$[48,57,58]$} \\
\hline & Polyphenoles & $\begin{array}{c}\text { Topoisomerase II } \\
\text { inhibition (growth arrest) }\end{array}$ & Colon carcinoma & Cell lines & [59] \\
\hline & 3,4-dihydroxybenzalacetone & $\begin{array}{c}\text { NF-kB inhibition- } \\
\text { mediated apoptosis, } \\
\text { suppression of invasion }\end{array}$ & $\begin{array}{l}\text { Gastric, liver, } \\
\text { colon cancer }\end{array}$ & Cell lines & {$[60]$} \\
\hline & Polysaccharides & $\begin{array}{l}\text { Tumor growth inhibition } \\
\text { via immunostimulation }\end{array}$ & $\begin{array}{l}\text { Colorectal cancer, } \\
\text { gastric cancer }\end{array}$ & $\begin{array}{l}\text { Mouse } \\
\text { xenograft } \\
\text { tumors }\end{array}$ & {$[47,61-63]$} \\
\hline & & $\begin{array}{l}\text { Migration inhibition, } \\
\text { anti-metastatic activities }\end{array}$ & Lung carcinoma & Cell lines & {$[64,65]$} \\
\hline & Ergosterol peroxide & $\begin{array}{l}\text { Inhibition of Wnt } \\
\text { signaling }\end{array}$ & Colorectal cancer & $\begin{array}{l}\text { Cell lines, } \\
\text { Mouse } \\
\text { xenograft } \\
\text { tumors }\end{array}$ & [66] \\
\hline & Inotodiol & & $\begin{array}{l}\text { Breast cancer. } \\
\text { lung cancer }\end{array}$ & $\begin{array}{l}\text { Cell lines } \\
\text { Rat model }\end{array}$ & {$[68,69]$} \\
\hline \multirow[t]{6}{*}{$\begin{array}{l}\text { Trametes } \\
\text { versicolor }\end{array}$} & Water-ethanol extract & $\begin{array}{c}\text { Cytotoxic/ } \\
\text { antiproliferative }\end{array}$ & $\begin{array}{l}\text { Breast cancer, } \\
\text { cervical cancer, } \\
\text { B-lymphoma, } \\
\text { hormone- } \\
\text { dependent liver } \\
\text { cancer }\end{array}$ & Cell lines & {$[72,73]$} \\
\hline & Ethanol extract & $\begin{array}{l}\text { Cytotoxic/ } \\
\text { antiproliferative }\end{array}$ & Prostate cancer & Cell lines & [74] \\
\hline & Glucans & Tumor growth inhibition & Sarcoma & $\begin{array}{l}\text { Mouse } \\
\text { xenograft } \\
\text { tumors }\end{array}$ & [75] \\
\hline & $\begin{array}{c}\beta \text {-glucan-based } \\
\text { polysaccharopeptide } \\
\text { fraction (PSP) }\end{array}$ & $\begin{array}{l}\text { Tumor growth inhibition } \\
\text { via immunostimulation }\end{array}$ & $\begin{array}{l}\text { Breast cancer, } \\
\text { gastrointestinal } \\
\text { cancer, lung } \\
\text { cancer }\end{array}$ & $\begin{array}{c}\text { Mouse } \\
\text { xenograft } \\
\text { tumors, clinical } \\
\text { trials }\end{array}$ & {$[76-81]$} \\
\hline & $\begin{array}{l}\text { Polysaccharide fraction } \\
\text { known as Krestin (PSK) }\end{array}$ & & & & {$[76,82-91]$} \\
\hline & YZP protein & Immunostimulation & Pancreatic cancer & $\begin{array}{l}\text { Cell lines, } \\
\text { Mouse } \\
\text { xenograft } \\
\text { tumors }\end{array}$ & [70] \\
\hline
\end{tabular}

agent cisplatin gave a synergistic effect on slowing down the tumor growth. Taken together, these findings provide a stronger evidence that apart from the unspecific cytotoxic compounds, $F$. pinicola contains substances possessing specific anti-oncogenic potential, probably acting through induction of apoptosis. Regarding the fact that $F$. pinicola is known as an anticancer agent in the Chinese folk medicine, we can conclude that this mushroom is of a 
certain interest for modern drug discovery as a potential source of novel anticancer compounds, which are yet to be characterized. Although ergosterol has been pinpointed as one of the candidates, the exact chemical nature of the acting compounds is still elusive. Biomolecular profiling of inedible mushrooms has revealed an unusually high phenolic content in $F$. pinicola, when compared to the others [15] and polyphenols are known to be bioactive compounds with anti-oncogenic properties [22]. Thus, detailed studies on polyphenoles of $F$. pinicola is a promising task for biomedicine.

\section{Hericium erinaceus}

Hericium erinaceus, class Agaricomycetes, order Russulales, family Hericiaceae, is an edible medicinal mushroom (Figure 2). It is also known under the name "Lion's mane" in English, "Yamabushitake" in Japan or " Hóutóugū" in China. [23].

The mushroom is considered a saprotroph or a weak parasite. It is found on oak (Quercus) and beech (Fagus) in Europe, North America, Japan, Russia, and China. [24]. H. erinaceus has attracted special scientific attention in recent four years, being intensively studied in terms of its primary and secondary metabolites and their possible medicinal use. It yielded a number of compounds belonging to different classes with potential biological activity, which were tested against multiple targets [25-27]. Among the isolated compounds, certain were characterized, such as erinacines derived from the mycelium or hericenones derived from the fruiting bodies [27]. A significant part of research has been focused on neuroprotective properties of the mushroom, which are now extensively described in many works [28]. Another large area of possible therapeutic and anti-carcinogenic application of $H$. erinaceus is its salutary influence on the digestive organs, including stomach, liver, intestine and colon. Water and ethanol extracts of the mushroom have demonstrated growth inhibitory effects on gastric (NCI87), liver (HepG2 and Huh-7), and colon (HT-29) cancer cell lines in the MTT proliferation assay, with the highest efficacy against Huh-7 cells (IC50 of $0.8 \mathrm{mg} / \mathrm{ml}$ for the dried extract). Although not comparing these results with non-cancer cell lines of the respective tissues, the same study describes efficient application of the extracts against xenograft tumors formed by aforementioned cancer cell

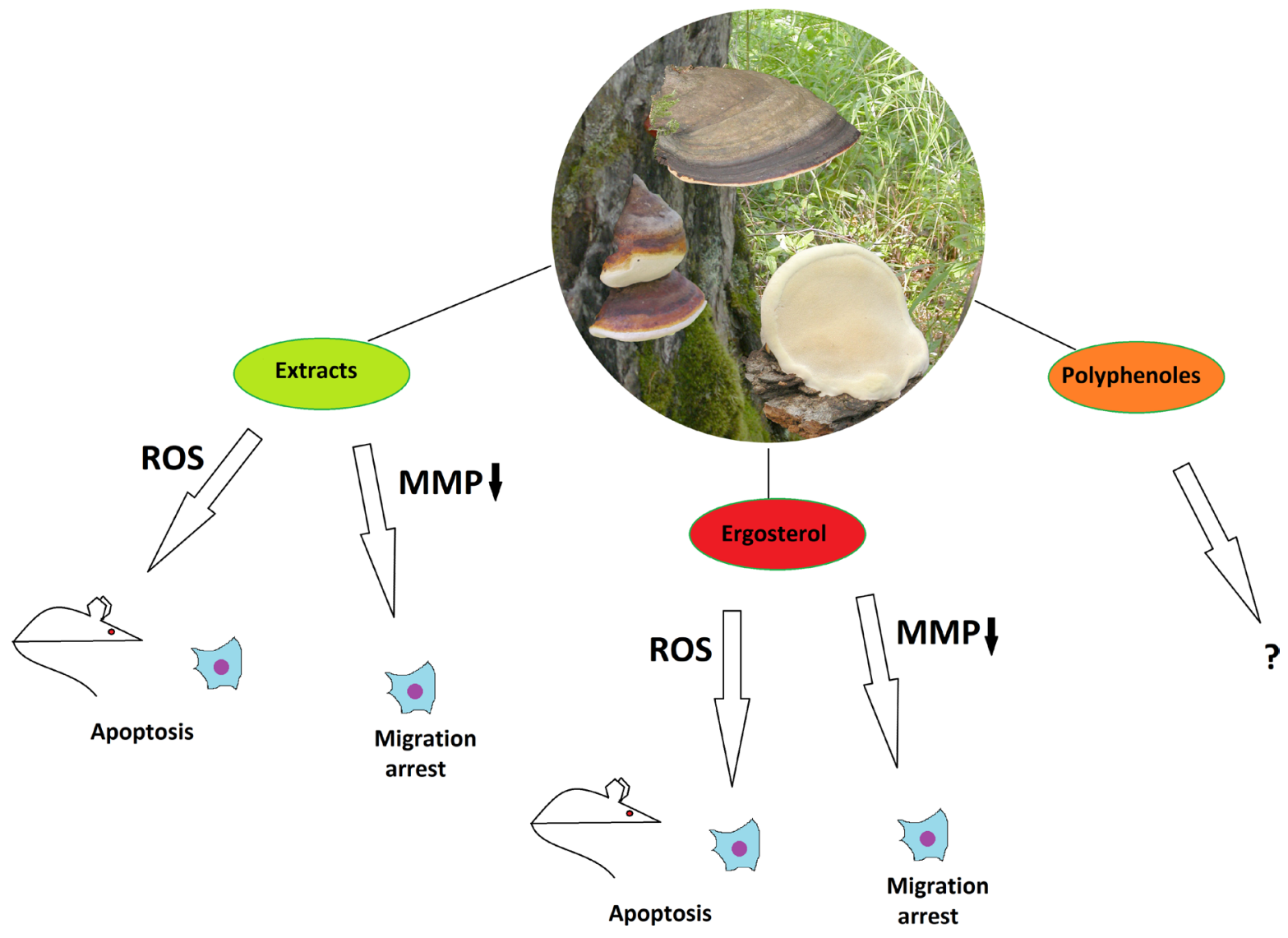

Figure 1: The anticancer properties of Fomitopsis pinicola. Effects of different mushroom derivatives and their mechanisms of actions on various models are depicted. Mouse and cell icons indicate results obtained on animal and cell models, respectively. ROS reactive oxygen species, MMP $\downarrow$ - downregulation of matrix metalloproteinases. 
lines in SCID mice. The extracts, given orally, have demonstrated a tumor suppressing activity similar to that of 5-fluoruracil, a most widely used drug clinically applied for the treatment of gastrointestinal cancers, but demonstrated a much lower general toxicity than 5-fluoruracil [29]. Another study shows that water extracts of $H$. erinaceus, given as a food supplement, possess an anti-metastatic activity, strongly inhibiting the migration of CT-26 murine colon carcinoma cells to lungs after intravenous injection into $\mathrm{BALB} / \mathrm{c}$ mice, reducing the formation of tumor nodules in the lung by about $50 \%$, and preventing metastasis-caused increase in the lung weight. The mechanism of action involves suppression of matrix melalloproteinases 2 and 9, as well as suppression of ERK and JNK kinase activation, also decreasing the general tumor cell viability [30].

Further research on tumor suppressing activity of the $H$. erinaceus extracts allowed to reveal the possible spectrum of their action modes. Studies on CT-26 derived human colon cancer xenograft tumors in mice have shown a significant reduction in tumor growth after treatment by H. erinaceus water extracts. It has been demonstrated that the extracts stimulated the activities of natural killer cells and macrophages on one hand and blocked angiogenesis on the other [30]. All these activities could contribute to reduction of the tumor growth, although the anticancer properties of the complex extract may not be limited by them. Another study by the same group has demonstrated a pro-apoptotic effect of same water extracts on U937 human monocytic leukemia cells in comparison to normal human and murine fibroblasts, as measured by flow cytometry. The mechanism of action is supposed to be down-regulation of anti-apoptotic proteins (Bcl-2, Bcl$\mathrm{xL}(\mathrm{S}), \mathrm{XIAP}$, and cIAPs), but not up-regulation of proapoptotic ones [31]. Further concerning the exploration of the immunomodulatory potential of $H$. erinaceus, it can be stated that polysaccharide fractions of the mushroom ethanol extract and derivatives thereof are able to promote dendritic cell maturation and dendritic cell-mediated cytokine production and T-cell proliferation [32], as well as to activate macrophages and increase $\mathrm{TNF} \alpha$ production [33]. Stimulatory effects on intestinal immune system, manifested mainly through increase of surface IgA expression and natural killer cell activation, have also been reported in mouse in vivo experiments, when the polysaccharide fraction of $H$. erinaceus was given as a food supplement [34]. Although these investigations give no clue upon the exact structural and chemical properties of the active polysaccharides, the idea of their immunomodulatory input into the anti-carcinogenic potential of $H$. erinaceus is very attractive.

Efforts to study anticancer effects of individual compounds isolated from $H$. erinaceus have produced impressive results. Cyanthine diterpenoid Erinacine A, a mycelial derivative of $H$. erinaceus, has demonstrated growth-inhibitory activities against different cancer cell lines and tumors related to the digestive tract. It was able to arrest the cell cycle through ROS-mediated activation of the oxidative stress response, initiating potentiation of the JNK1/2 MAPKs, p70S6K and mTOR pathways in human colorectal adenocarcinoma cell line DLD-1. It also showed significant proliferation decrease of the

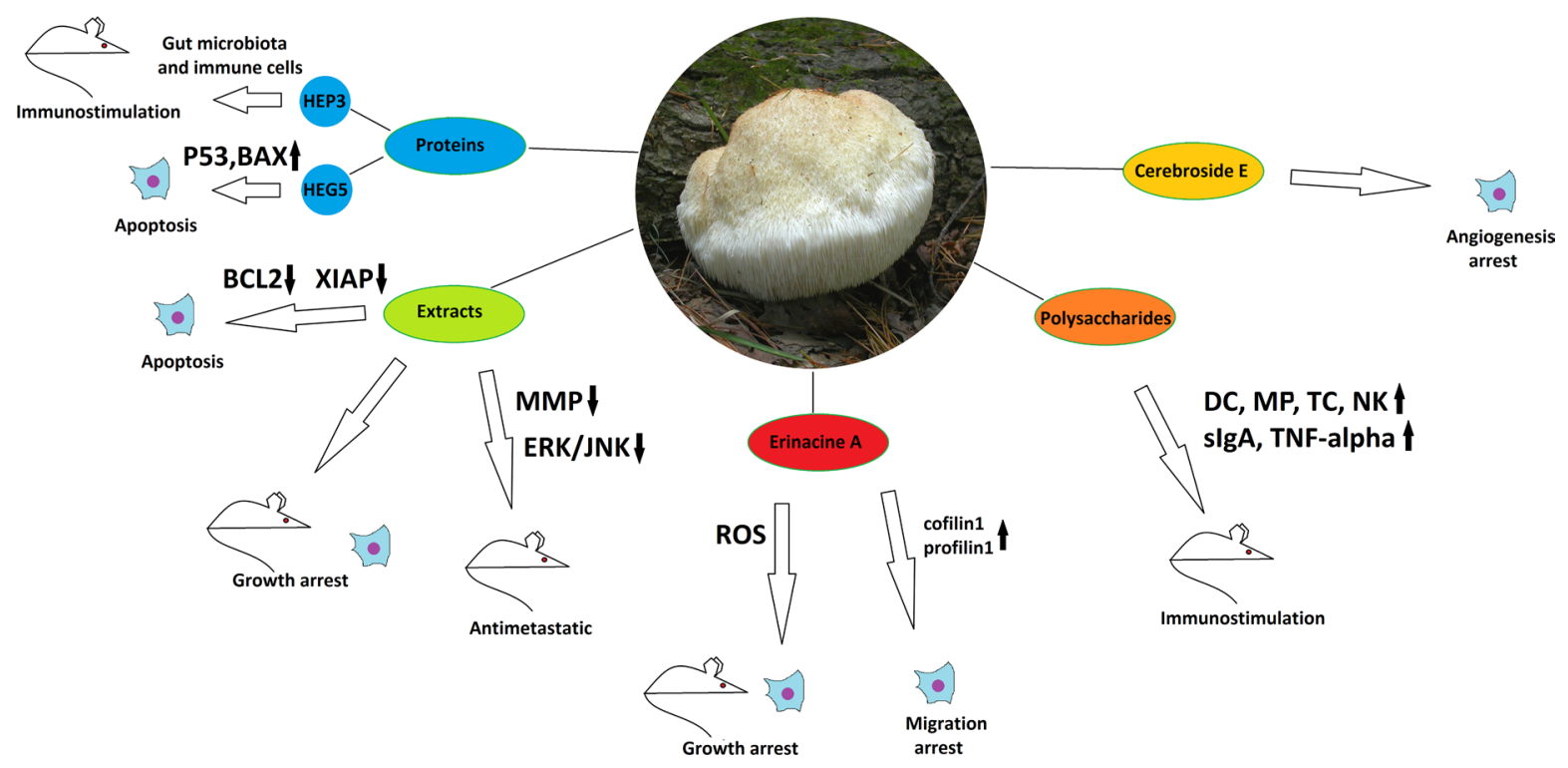

Figure 2: The anticancer properties of Hericium erinaceus. Effects of different mushroom derivatives and their mechanisms of actions in various models are depicted. Mouse and cell icons indicate results obtained on animal and cell models, respectively. Arrows up and down reflect up- or down-regulation of respective proteins or pathways. ROS - reactive oxygen species, MMP - matrix metalloproteinases, DC - dendritic cells, MP - macrophages, TC - T-cells, NK - natural killers. Other proteins/pathways are mentioned under their standard names. 
DLD-1 and other colorectal cancer cell line HCT-116 in comparison to the normal human colonic epithelial cells when analyzed by the MTT assay. Finally, Erinacine A has demonstrated an in vivo inhibition of DLD-1 xenograft tumor growth in nude mice [35]. The anticancer activity of Erinacine A mediated by ROS accumulation has also been confirmed by comparative proteomic assays in human gastric cancer cell lines MKN28 and TSGH9201 [36]. Further studies have also shed light on anti-invasive properties of Erinacin A, which it demonstrated on DLD1 and HCT-116 colorectal cancer cells in the Boyden chamber and scratch wound healing assays. Proteomic studies have revealed the actin-binding proteins cofilin-1 and profilin-1 as downstream actors activated by the Erinacine A-induced ROS response and mediating the anti-invasive effect [37]. Another class of compounds common for fungi are cerebrosides, and here cerebroside $\mathrm{E}$ isolated from $H$. erinaceus has shown an ability to inhibit (although slightly) the tube formation in the HUVEC cell culture, thus being a potential angiogenesis blocker. This compound also revealed antitoxic properties, reducing the damage of LLC-PK1 kidney cells after cisplatin treatment in culture - properties that may suggest it for the use in complex cancer chemotherapies [38].

Interestingly, $H$. erinaceus is not merely a source of low molecular weight biologically active compounds, but also of some proteins that possess potential tumor-suppressive activities. Indeed, a Hericiumderived protein HEP3, which demonstrated a complex immunomodulatory impact in mice, has also been able to strongly reduce growth of CC531 cell xenograft tumors after intraperitoneal injection. The immunomodulatory effect was induced through stimulation of the gut microbiota with the protein and involved activation of the proliferation and differentiation of T-cells and stimulation of the intestinal antigen-presenting cells [39]. Another example of bioactive protein from the same mushroom is a glycoprotein HEG-5 that was able to induce apoptosis in a gastric cancer cell line SGC-7901, stimulating the expression of pro-apoptotic factors such as p53, Bax, Caspase 8 and Caspase 3 [40].

Another possible, though indirect, activity of $H$. erinaceus, which can be relevant for the gastric cancer is the ability of the fungal extracts to remediate gastrointestinal ulcers which, on their turn, can be classified as carcinogenic conditions. H. erinaceus has been used to treat gastritis and gastroduodenic ulcer in the Chinese folk medicine [41]. Ethanol extracts of $H$. erinaceus have shown a cytoprotective effect after treatment of alcohol-induced gastric ulcers in rats [42].

H. erinaceus is also able to inhibit growth of Helicobacter pylori, the bacterium known to be the causative agent for gastritis and ulcer. Analyses of petroleum ether extracts of the mushroom have been performed, showing ability of the extracts to suppress the growth of six Helicobacter pylori strains in the microdilution assay and in the disk diffusion assay in vitro. Separation of the extracts yielded two active compounds, namely the 1-(5-chloro-2-hydroxyphenyl)3-methyl-1-butanone and the 2,5-bis(methoxycarbonyl) terephthalic acid, which were responsible for the inhibitory activity [43]. A polysaccharide composed of glucose, mannose, and galactose isolated from the cultured mycelia of $H$. erinaceus [44] was able to show antioxidant properties on gastric mucosa cell line GES1 after hydrogen peroxide treatment, which makes this polysaccharide a good candidate for one of components responsible for the mushroom's gastroprotective effect [45].

Regarding the overall anticancer potential of Hericium erinaceus, it can be stated that this medicinal mushroom possesses a complex of active compounds, which are able to block tumorigenesis at different stages and by different mechanisms; most of them are confirmed by both cell culture and xenograft experiments. It has been demonstrated that $H$. erinaceus extracts or fractions/ components thereof exhibit: (i) immunostimulatory activities, (ii) anti-metastatic activities through inhibition of matrix metalloproteinases, (iii) gastro- and intestineprotective activities, (iv) antioxidant potential, (v) proapoptotic activities, (vi) inhibition of angiogenesis. This spectrum of anticancer properties is provided by different compounds: polysaccharides, lipids, terpenoids (including unique erinacines), and even proteins. Thus, two possible strategies of application of $H$. erinaceus to cancer treatment are possible: studies on the complex action of the extracts on patients with their further use as cancer-preventive food supplements, and the detailed investigation of compounds isolated from the mushroom and their mechanisms of action for using them in targeted, personalized anticancer therapy of the future. Up to date, most of the cancer-related research of the mushroom has focused on (though not limited by) gastrointestinal tumors. Many preclinical trials on tumor-bearing mice indicate $H$. erinaceus as a promising candidate for therapeutic use in this field. Nevertheless, up to date no clinical trials on the mushroom or compounds thereof exist, moreover, many active compounds are still unidentified, and many mechanisms of their action remain elusive. Thus, Hericium erinaceus is a relatively well-studied medicinal mushroom possessing a much larger therapeutic potential for the future compared to its currently exploited applications. Regarding the possibility to culture this mushroom on industrial scale [46], it has a great chance to become a part of modern natural products-based medicinal biotechnology.

\section{Inonotus obliquus}

The mushroom Inonotus obliquus, class Agaricomycetes, order Hymenochaetales, family Hymenochaetaceae (also known as Chaga mushroom, Figure 3 ) is a fungus that preferably grows as parasite 
on the trunks of living birch trees in the colder northern climates [47].

I. obliquus has long been used in folk medicine for cancer treatment in Russia, China, Korea and Japan [48-50]. Water extracts of I. obliquus have demonstrated cytotoxic and antimitotic activity on HeLa cells [51]. Extracts obtained from the mushroom by submerged fermentation induced apoptosis in the human colorectal carcinoma cell lines HCT-116 [52] and HT-29 [53]. Similar low-specific cytotoxic and/or cytostatic effects of the Chaga extracts were reported on human colon cancer cells [53] and liver cancer HepG2 cells [54] without, however, elucidating the mechanisms of action. In vivo experiments with I. obliquus extracts have provided data on reduction of tumor growth by induction of apoptosis in human melanoma B16-F10 cells-derived xenografts in mice [55]. Growth of human Sarcoma-180 cells-derived xenografts was as well suppressed by different subfractions of the Chaga extract [56].

Regarding the anticancer potential of individual compounds of I. obliquus, several groups can be highlighted for this mushroom. Unique lanostan-type triterpenoids inonotodiol and inonotsuoxides have revealed anti-carcinogenic effects in vivo using the mouse skin [48, 57] and human leukemia-derived mouse xenograft tumors [58]. Low molecular weight polyphenolic compounds demonstrated a topoisomerase II inhibiting activity leading to growth reduction in cultured human colon HCT116 carcinoma cells, identifying these polyphenoles as putative anticancer chemotherapeutic agents [59]. Another Chaga-derived polyphenol, 3,4-dihydroxybenzalacetone, inhibited the NF- $\kappa \mathrm{B}$ activation and NF- $\kappa \mathrm{B}-$ dependent gene expression in a panel of human cancer cell lines through blockade of IкBalpha (a subunit of NF-kappaB) phosphorylation and inhibition of NF- $\kappa \mathrm{B}$ activity followed by suppression of synthesis of TNF-induced and NF- $\kappa \mathrm{B}-$ dependent proliferative, anti-apoptotic and pro-metastatic gene products. These effects led to increase of TNFinduced apoptosis and decrease of TNF-induced invasion [60]. As Hericium erinaceus, the Chaga mushroom is extremely rich in polysachharides, which may perform immunomodulatory functions and inhibit tumorigenesis. In vivo trials of different Chaga-derived polysaccharides with different mouse xenograft tumor models have demonstrated reduction of tumor growth along with immunostimulatory effects [61-63]. Polysaccharides from I. obliquus have also demonstrated anti-metastatic activities and inhibition of migration in cancer cell culture experiments, by blocking the expression and activity of matrix metalloproteinases 2 and 9 via suppression of MAPKs, PI3K/AKT, and NF- $\kappa \mathrm{B}$ signaling pathways $[64,65]$. It is also important to highlight that the Chaga mushroom contains ergosterol peroxide that has been reported to inhibit growth of several human colorectal cancer cell lines and of colon tumors in a mouse model through the mechanism of $\mathrm{Wnt} / \beta$-catenin pathway downregulation [66]. This is particularly important, because over-activation of this pathway is a cause of many cancer types, such as colon, liver and breast and, moreover, is highly specific to cancer in adult patients being virtually inactive in healthy tissues [67]. Nevertheless, it has to be pinpointed that the most recent studies confirm the Wnt/ $\beta$ catenin-inhibitory properties of the Chaga mushroom but indicate other major compound as the active one, namely

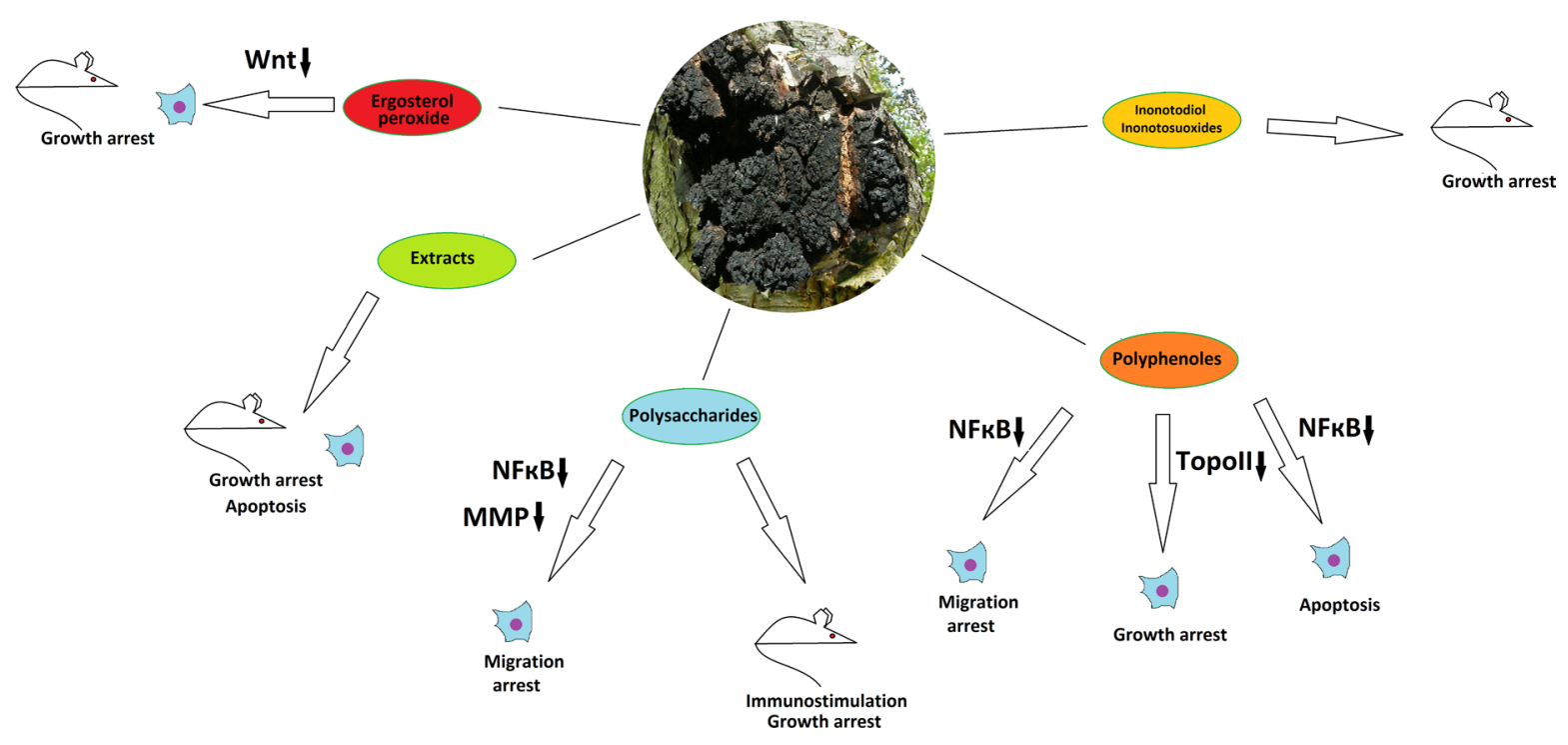

Figure 3: The anticancer properties of Inonotus obliquus. Effects of different mushroom derivatives and their mechanisms of actions in various models are depicted. Mouse and cell icons indicate results obtained on animal and cell models, respectively. Arrows up and down reflect up- or down-regulation of respective proteins or pathways. ROS - reactive oxygen species, MMP - matrix metalloproteinases, TopoII - topoisomerase II. Other proteins/pathways are mentioned under their standard names. 
the inotodiol, which efficiently suppressed Wnt-dependent breast cancer proliferation under diabetic conditions in a rat model [68]. As ergosterol is also found in other medicinal mushrooms including Fomitopsis pinicola discussed above, it can be one of important components of targeted cancer fungotherapy in general. Recent HPLCtandem mass-spectrometry study of Chaga mushrooms derived from France, Canada and Ukraine suggests that the Chaga of French origin is the most rich on betulin and betulinic acid, whereas Canadian Chaga is more rich on inotodiol [69]. Taken together, the Chaga mushroom can be regarded as a very promising but somewhat understudied species, because in spite of its broad use in folk medicine and of promising activities of extracts and certain compounds against cancer in vitro and in vivo, not many exact mechanisms of action are determined and no clinical trials on human patients have been performed.

\section{Trametes versicolor}

Trametes versicolor, class Agaricomycetes, order Polyporales, family Polyporaceae (Figure 4), is a medicinal mushroom also known as Coriolus versicolor or Polyporus versicolor, "Yun-Zhi" in China, "Kawaratake" in Japan, and "Turkey tail mushroom" in English. This fungus has been used as a therapeutic agent worldwide [70]. It grows on tree trunks throughout the world in many diverse climates, including North America [71].

A solid body of data exists on $T$. versicolor cytotoxic, cytostatic and pro-apoptotic actions on various cancer cell lines. Water-ethanol extracts of the mushroom caused the proliferation inhibition on three human breast cancer cell lines (T-47D, ZR75-30 and MCF-7), human cervical cancer cell line Bcap37, human B-cell lymphoma (Raji), human promyelocytic leukemia (HL60, NB-4), and human liver cancer cell line 7703 [72, 73]. Such results do not prove anticancer function per se, but provide some clues and fit well within the context of other, more detailed data. Other studies have shown antiproliferative effects of an aqueous extract of $T$. versicolor on human breast cancer (4T1), prostate cancer (DU145), and hepatocellular carcinoma (HCC), when compared to rat normal intestinal epithelial cells (IEC-6), and African green monkey normal kidney (Vero) cell lines using the MTT assay. The results demonstrated that the $T$. versicolor extract was able to inhibit proliferation of DU145 and 4T1 cell lines in a dose-dependent way. The extract however did not exert any significant anti-proliferative effect on HCC, IEC-6, and Vero cell lines $\left(\mathrm{IC}_{50}>1000 \mu \mathrm{g} / \mathrm{ml}\right)$, showing its selective cytotoxicity for certain types of cancer and its safety for normal cell lines. Studies of the T. versicolor ethanol extract effects on human prostate cancer cell lines have demonstrated the selectivity towards inhibition of growth of the androgen-responsible cell line LNcAP, while producing slight or no effect on hormoneindependent lines PC-3, DU-145, and JCA-1 [74].
Separation of $T$. versicolor extracts has yielded many fractions and compounds, exhibiting targeted impact on cancer cells in vivo and in vitro. The most remarkable among them is the polysaccharide fraction which, along with some isolated carbohydrates and proteoglycans, possessed complex immunomodulatory potential similar to that of Hericium erinaceus and relevant for the anticancer treatment. As a recent example, a new glucan has been isolated from this mushroom by hot water extraction and subsequent chromatographic purification and has demonstrated an ability to significantly inhibit the xenograft sarcoma growth in mice [75]. Most clinically relevant representatives of $T$. versicolor-derived polysaccharides are the $\beta$-glucanbased polysaccharopeptide fraction (PSP) and the polysaccharide fraction known as Krestin (PSK) [76]. Both have underwent excessive clinical and preclinical studies as immunotherapeutic anticancer agents [77]. Immunotherapy employing PSP has already become a routine clinical practice in Japan since 1977 and in China since 1987. PSP activates cells of the immune system, boosts production of cytokines and chemokines such as TNF $\alpha$, interleukins (IL-1 $\beta$ and IL-6), histamine, and prostaglandin E, stimulates dendritic and T-cell infiltration into tumors and reduces the harmful side effects of chemotherapy [78]. Some studies have been performed to reveal the mechanism of PSP interaction with the immune system. Experiments on peripheral blood mononuclear cells from breast cancer patients have shown that PSP drives cytokine expression through activation of the TLR4-TIRAP/MAL-MyD88 signaling pathway [79]. It has also been found out that PSP treatment leads to increased proliferation of the peripheral blood monocytes, but does not directly affect the proliferation of T, B, and NK cells [80]. Nevertheless, orally given combination of PSP with acaccia resin as an adjuvant has led to a significant increase of a hapten-induced specific T-cell dependent B-cell response in mice, suggesting a complex mechanism of PSP action [81]. The T. versicolor-derived polysaccharide Krestin is an even more widespread and better-studied immunomodulator used for anticancer treatment. It is able to activate different types of immune cells. PSK has shown the ability to stimulate dendritic cells through the TLR2 receptor in vitro and to inhibit breast cancer growth in the mouse model with the antitumor effect dependent on $\mathrm{CD}^{+} \mathrm{T}$-cell and NK cells, but not $\mathrm{CD}^{+}$T-cells. PSK did not inhibit tumor growth in TLR2/- demonstrating that it is a specific TLR2 agonist and has potent antitumor effects via activation of both innate and adaptive immunity $[82,83]$. In another study, PSK enhanced the effect of trastuzumab-mediated anti-breast cancer therapy when given orally, activating the NK cells both directly and via interleukin-12 [84]. PSK has also been able to activate murine macrophages via the TLR4 pathway, inducing TNF $\alpha$ and IL-6 secretion by wild type but not by TLR4-deficient peritoneal macrophages [85]. It 
as well potentiated docetaxel-induced tumor suppression and antitumor immune response in an immunocompetent murine model of human prostate cancer [86]. Recent studies indicate that the TLR2 agonist in PSK is a lipid component, which acts cooperatively with the proteinbound $\beta$-glucan [87].

Interestingly, a protein YZP purified from T.versicolor has demonstrated a related ability: specific triggering of differentiation of CD1 $\mathrm{d}^{+} \mathrm{B}$ cells into IL-10producing regulatory $\mathrm{B}$-cells, which promote the antiinflammatory function [70]. It is also worth-mentioning that PSK has been shown to downregulate the overactivated Hedgehog signaling cascade under hypoxic conditions and to suppress the malignant phenotype in pancreatic cancer in vitro and in mouse models [88]. This may be extremely important, for Hedgehog upregulation is a well-known hallmark of many cancer types and a desired therapeutic target [89]. Here we, again, observe a complex and synergistic action of several chemically diverse compounds from the same fungal species. Nevertheless, results on clinical trials exist that do not prove high therapeutic efficacy of PSK in human patients. Indeed, in Japan, PSK has been used for adjuvant immunotherapy against gastric cancer. Patients with stage II/III gastric cancer who underwent a surgical resection were included into a retrospective study. All patients received oral fluorinated pyrimidine anti-metabolites with or without PSK after the operation, and no significant difference between the control and the PSK group in relapse free survival was detected [90]. Such examples reflect that not all data obtained in model systems are applicable to real clinical practice, and cancer therapies have to be chosen very carefully to yield the desired effects. Successful applications of PSK in human patients have been demonstrated when the polysaccharide was applied to treat lung cancer. Different sets of data on non-randomized and randomized controlled clinical trials exist that show improvement of various survival measures including median survival and 1-, 2-, and 5-year survival, improvement of immune function and reduction of tumorassociated symptoms [91]. In any case, larger and more rigorous randomized controlled trials for PSK in lung cancer patients have to be performed [91].

Alongside the lung cancer, $T$. versicolor-derived products are clinically applicable for the treatment of breast cancer [71]. Many studies and some clinical trials exist that describe the effect of the mushroom in animal models and human patients. Thus, a natural dietary supplement BreastDefend, which contains extracts from medicinal mushrooms including $T$. versicolor, inhibits proliferation and metastasis formation by the MDAMB-231 invasive human triple-negative breast cancer

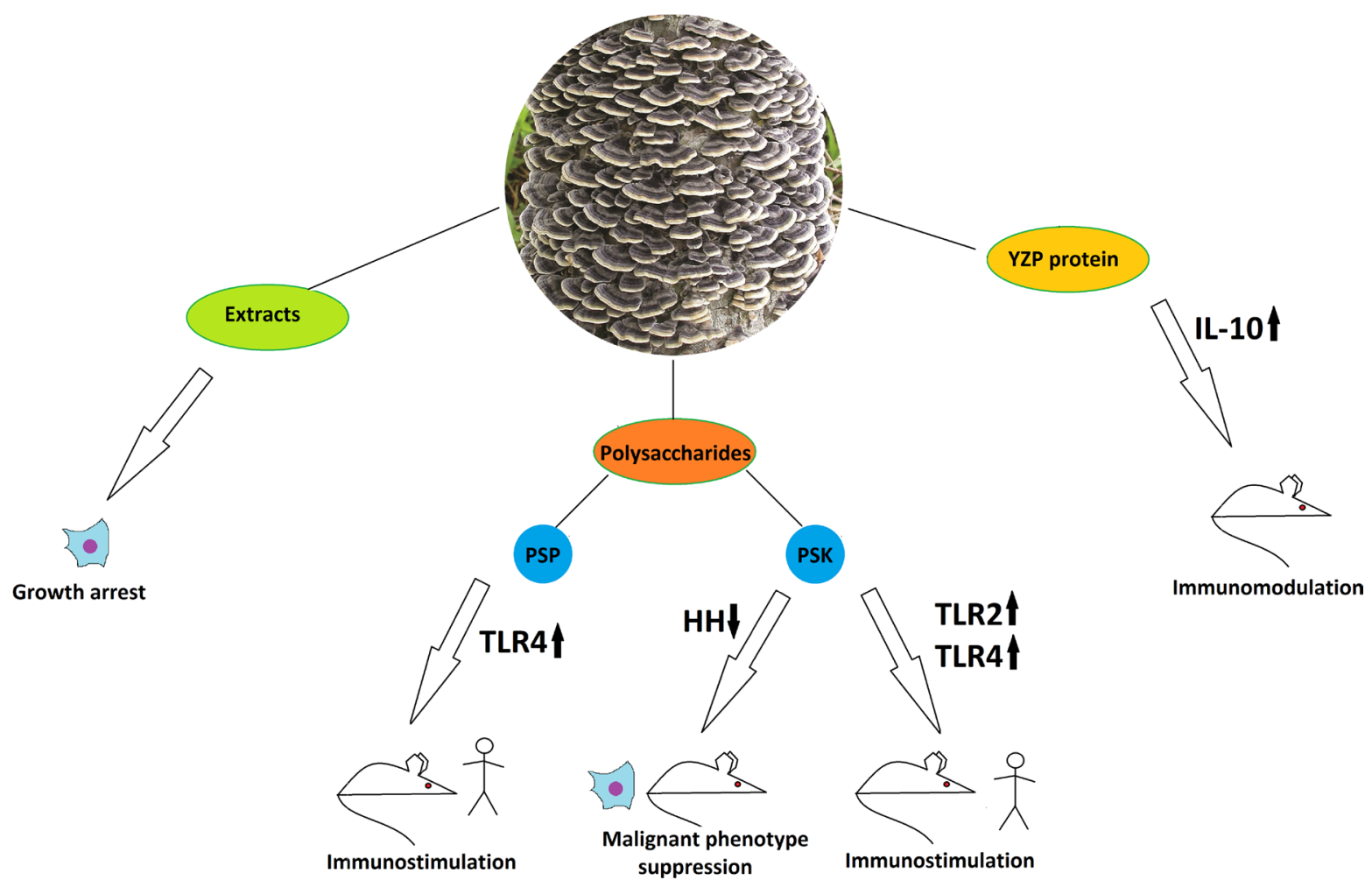

Figure 4: The anticancer properties of Trametes versicolor. Effects of different mushroom derivatives and their mechanisms of actions in various models are depicted. Human, mouse and cell icons indicate results obtained in human patients, animal and cell models, respectively. Arrows up and down reflect up- or down-regulation of respective proteins or pathways. PSP - polysaccharopeptide, PSK polysaccharide Krestin, HH - Hedgehog pathway, TLR2, TLR4 - Toll-like receptors 2 and 4. IL-10 - Interleukin 10. 
cells in culture and suppresses their growth and breast-to lung cancer metastasis in a xenograft mouse model [92]. There are single-case reports [93] and Phase I clinical trial results [86] confirming that $T$. versicolor-based treatment may be used as a supplement to conventional anti-breast cancer therapy and lead to improvements of the immune status in immunocompromised breast cancer patients following standard primary oncologic treatment. The mushroom preparations are widely used in up-todate integrative oncology and prescribed to patients on a regular basis [94].

In general, $T$. versicolor can be characterized as a medicinal mushroom, which is most actively used in modern medicine in terms of anticancer treatment compared to the other species discussed in this review. It is mostly used as an adjuvant for cancer immunotherapy, with data on clinical trials available, and has led to development of several commercial medicines, mostly acting as activators of the immune cells by the mushroom polysaccharide fractions through Toll-like receptors. Nevertheless, data on selective growth inhibition of certain cancer cell lines in culture, without any immune cells involved, suggest that there may be other specific mechanisms of action at play, besides the ones described before.

\section{CONCLUSIONS}

The complex anticancer potential of medicinal mushrooms may be embodied not only through inhibition of certain cancer-specific processes or targeted activation of tumor-specific apoptosis, but also through indirect actions such as immunomodulation [95]. The polysaccharide-mediated antitumor immunomodulatory action seems to be rather common for many medicinal mushrooms and gives a major input into the therapeutic potential of at least three out of the four reviewed species, which is probably determined by similar carbohydrate composition and thus similar effects on the immune system of different mushrooms. Extrapolating these data, we can suppose that other, less studied, polysacchariderich mushroom species could possess similar or even superior immuno-stimulatory properties. Moreover, some of additional biological activities can be used for cancer prevention, diminishing the risk of tumorigenic conditions; to such activities we can attribute antioxidant, antibacterial and anti-inflammatory properties. That is why research on whole fungal extracts (sometimes reaching to the clinical trials) and even on extracts of complex mixtures of different medicinal mushrooms [96] are the important part of the given research field.

The four mushrooms reviewed in this article illustrate different stages of natural product-derived drug development. Each medicinal plant or fungus undergoes multiple stages of extraction, fractionation and purification of active compounds. At the same time these extracts, fractions and compounds are tested against different cancer models, from tumor-derived cell lines to animal models and clinical trials. Another dimension is studying the mechanisms-of-action and targets of the natural products and their derivatives. Maximum progress in all these trials brings us closer to a perfect natural drug for targeted cancer therapy. The mushroom discussed first in our review, Fomitopsis pinicola, is closer to the initial stages of involvement into modern cancer treatment: it is known to possess certain anticancer activities, and a set of compounds were isolated, but experiments on animal models and clinical trials are lacking, as well as precise studies on the molecular targets and signaling pathways affected by the fungus. Inonotus obliquus is a better-studied mushroom: here we have more data on mouse xenograft experiments and more molecular targets, including the $\mathrm{Wnt} / \beta$-catenin pathway, a promising target for anticancer drugs of the future, but the medical relevance is still to be improved by clinical trials. Hericium erinaceus and especially Trametes versicolor are much more advanced in terms of medical applications due to their uncovered strong and complex immunomodulatory potential provided by rich polysaccharide and proteoglycan diversity. There are numerous clinical trials confirming applicability of these mushrooms and their extracts as components of modern anticancer chemotherapy. But the complex modes of action and molecular targets as well as exact structures of the active molecules from these mushrooms still have to be studied in more detail. In general, there has been a strong progress in the field of medicinal mushroom research in terms of anticancer drug development, but this work continues and much more progress still awaits us, especially in the fields of molecular targets of the medicinal mushrooms and the complex synergistic interplay of their different components.

\section{ACKNOWLEDGMENTS}

The work was supported by Ministry of Education and Science of the Russian Federation (project \# 6.7997.2017/8.9). The photographs of the mushrooms were kindly provided by Eugenia M. Bulakh.

\section{CONFLICTS OF INTEREST}

The authors declare that there are no conflicts of interest between them for this manuscript.

\section{REFERENCES}

1. Wall ME, Wani MC, Cook CE, Palmer KH, McPhail AT, Sim GA. Plant Antitumor Agents. I. The Isolation and Structure of Camptothecin, a Novel Alkaloidal Leukemia and Tumor Inhibitor from Camptotheca acuminata1,2. 
Journal of the American Chemical Society. 1966; 88:388890. https://doi.org/10.1021/ja00968a057.

2. van Der Heijden R, Jacobs DI, Snoeijer W, Hallard D, Verpoorte R. The Catharanthus alkaloids: pharmacognosy and biotechnology. Curr Med Chem. 2004; 11:607-28.

3. Wani MC, Taylor HL, Wall ME, Coggon P, McPhail AT. Plant antitumor agents. VI. The isolation and structure of taxol, a novel antileukemic and antitumor agent from Taxus brevifolia. J Am Chem Soc. 1971; 93:2325-7.

4. Hanahan D, Weinberg RA. Hallmarks of cancer: the next generation. Cell. 2011; 144:646-74. https://doi. org/10.1016/j.cell.2011.02.013.

5. Xu TT, Beelman RB, Lambert JD. The Cancer Preventive Effects of Edible Mushrooms. Anti-Cancer Agents in Medicinal Chemistry. 2012; 12:1255-63. https://doi. org/10.2174/187152012803833017.

6. Hao YF, Jiang JG. Origin and evolution of China Pharmacopoeia and its implication for traditional medicines. Mini Rev Med Chem. 2015; 15:595-603.

7. Shikov AN, Pozharitskaya ON, Makarov VG, Wagner H, Verpoorte R, Heinrich M. Medicinal Plants of the Russian Pharmacopoeia; their history and applications. Journal of Ethnopharmacology. 2014; 154:481-536. https://doi. org/10.1016/j.jep.2014.04.007.

8. Byerrum RU, Clarke DA, Lucas EH, Ringler RL, Stevens JA, Stock CC. Tumor inhibitors in Boletus edulis and other Holobasidiomycetes. Antibiot Chemother (Northfield). 1957; 7:1-4.

9. Rosecke J, Pietsch M, Konig WA. Volatile constituents of wood-rotting basidiomycetes. Phytochemistry. 2000; 54:747-50. https://doi.org/10.1016/ S0031-9422(00)00138-2.

10. Keller AC, Maillard MP, Hostettmann K. Antimicrobial steroids from the fungus Fomitopsis pinicola. Phytochemistry. 1996; 41:1041-6. https://doi. org/10.1016/0031-9422(95)00762-8.

11. Zjawiony JK. Biologically active compounds from Aphyllophorales (polypore) fungi. J Nat Prod. 2004; 67:300-10. https://doi.org/10.1021/np030372w.

12. Grienke U, Zoll M, Peintner U, Rollinger JM. European medicinal polypores - A modern view on traditional uses. Journal of Ethnopharmacology. 2014; 154:564-83. https:// doi.org/10.1016/j.jep.2014.04.030.

13. Usui T, Hosokawa S, Mizuno T, Suzuki T, Meguro H. Investigation of the heterogeneity of heterogalactan from the fruit bodies of Fomitopsis pinicola, by employing concanavalin A-Sepharose affinity chromatography. J Biochem. 1981; 89:1029-37.

14. Khadhri A, Aouadhi C, Aschi-Smiti S. Screening of Bioactive Compounds of Medicinal Mushrooms Collected on Tunisian Territory. International Journal of Medicinal Mushrooms. 2017; 19:127-35. https://doi.org/10.1615/ IntJMedMushrooms.v19.i2.40.
15. Reis FS, Pereira E, Barros L, Sousa MJ, Martins A, Ferreira ICF. Biomolecule Profiles in Inedible Wild Mushrooms with Antioxidant Value. Molecules. 2011; 16:4328-38. https://doi.org/10.3390/molecules16064328.

16. Choi D, Park SS, Ding JL, Cha WS. Effects of Fomitopsis pinicola extracts on antioxidant and antitumor activities. Biotechnology and Bioprocess Engineering. 2007; 12:51624. https://doi.org/10.1007/Bf02931349.

17. Yoshikawa $\mathrm{K}$, Inoue $\mathrm{M}$, Matsumoto $\mathrm{Y}$, Sakakibara C, Miyataka H, Matsumoto H, Arihara S. Lanostane triterpenoids and triterpene glycosides from the fruit body of Fomitopsis pinicola and their inhibitory activity against COX-1 and COX-2. Journal of Natural Products. 2005; 68:69-73. https://doi.org/10.1021/np040130b.

18. Ren G, Liu XY, Zhu HK, Yang SZ, Fu CX. Evaluation of cytotoxic activities of some medicinal polypore fungi from China. Fitoterapia. 2006; 77:408-10. https://doi. org/10.1016/j.fitote.2006.05.004.

19. Shnyreva AV, Shnyreva AA, Espinoza C, Padron JM, Trigos A. Antiproliferative Activity and Cytotoxicity of Some Medicinal Wood-Destroying Mushrooms from Russia. Int J Med Mushrooms. 2018; 20:1-11. https://doi.org/10.1615/ IntJMedMushrooms.2018025250.

20. Wang Y, Cheng X, Wang P, Wang L, Fan J, Wang X, Liu Q. Investigating migration inhibition and apoptotic effects of Fomitopsis pinicola chloroform extract on human colorectal cancer SW-480 cells. PLoS One. 2014; 9:e101303. https:// doi.org/10.1371/journal.pone.0101303.

21. Wu HT, Lu FH, Su YC, Ou HY, Hung HC, Wu JS, Yang YC, Chang CJ. In Vivo and In Vitro Anti-Tumor Effects of Fungal Extracts. Molecules. 2014; 19:2546-56. https://doi. org/10.3390/molecules19022546.

22. Colomer R, Sarrats A, Lupu R, Puig T. Natural Polyphenols and their Synthetic Analogs as Emerging Anticancer Agents. Current Drug Targets. 2017; 18:147-59. https://doi.org/10.2 174/1389450117666160112113930.

23. Thongbai B, Rapior S, Hyde KD, Wittstein K, Stadler M. Hericium erinaceus, an amazing medicinal mushroom. Mycological Progress. 2015; 14:91. https://doi.org/10.1007/ s11557-015-1105-4.

24. Boddy L, Crockatt ME, Ainsworth AM. Ecology of Hericium cirrhatum, H. coralloides and $H$. erinaceus in the UK. Fungal Ecology. 2011; 4:163-73. https://doi. org/10.1016/j.funeco.2010.10.001.

25. He X, Wang X, Fang J, Chang Y, Ning N, Guo H, Huang L, Huang X, Zhao Z. Structures, biological activities, and industrial applications of the polysaccharides from Hericium erinaceus (Lion's Mane) mushroom: A review. Int J Biol Macromol. 2017; 97:228-37. https://doi. $\operatorname{org} / 10.1016 /$ j.ijbiomac.2017.01.040.

26. Khan MA, Tania M, Liu R, Rahman MM. Hericium erinaceus: an edible mushroom with medicinal values. $\mathrm{J}$ Complement Integr Med. 2013; 10. https://doi.org/10.1515/ jcim-2013-0001. 
27. Friedman M. Chemistry, Nutrition, and Health-Promoting Properties of Hericium erinaceus (Lion's Mane) Mushroom Fruiting Bodies and Mycelia and Their Bioactive Compounds. Journal of Agricultural and Food Chemistry. 2015; 63:7108-23. https://doi.org/10.1021/acs.jafc.5b02914.

28. Phan CW, David P, Naidu M, Wong KH, Sabaratnam V. Therapeutic potential of culinary-medicinal mushrooms for the management of neurodegenerative diseases: diversity, metabolite, and mechanism. Critical Reviews in Biotechnology. 2015; 35:355-68. https://doi.org/10.3109/0 7388551.2014 .887649 .

29. Li G, Yu K, Li F, Xu K, Li J, He S, Cao S, Tan G. Anticancer potential of Hericium erinaceus extracts against human gastrointestinal cancers. J Ethnopharmacol. 2014; 153:52130. https://doi.org/10.1016/j.jep.2014.03.003.

30. Kim SP, Nam SH, Friedman M. Hericium erinaceus (Lion's Mane) mushroom extracts inhibit metastasis of cancer cells to the lung in CT-26 colon cancer-tansplanted mice. J Agric Food Chem. 2013; 61:4898-904. https://doi.org/10.1021/ jf400916c.

31. Kim SP, Kang MY, Choi YH, Kim JH, Nam SH, Friedman M. Mechanism of Hericium erinaceus (Yamabushitake) mushroom-induced apoptosis of U937 human monocytic leukemia cells. Food Funct. 2011; 2:348-56. https://doi. org/10.1039/c1fo10030k.

32. Qin T, Ren Z, Huang Y, Song Y, Lin D, Li J, Ma Y, Wu X, Qiu F, Xiao Q. Selenizing Hericium erinaceus polysaccharides induces dendritic cells maturation through MAPK and NF-kappaB signaling pathways. Int J Biol Macromol. 2017; 97:287-98. https://doi.org/10.1016/j. ijbiomac.2017.01.039.

33. Ren Z, Qin T, Qiu F, Song Y, Lin D, Ma Y, Li J, Huang Y. Immunomodulatory effects of hydroxyethylated Hericium erinaceus polysaccharide on macrophages RAW264.7. Int J Biol Macromol. 2017; 105:879-85. https://doi. org/10.1016/j.ijbiomac.2017.07.104

34. Sheng XT, Yan JM, Meng Y, Kang YY, Han Z, Tai GH, Zhou YF, Cheng HR. Immunomodulatory effects of Hericium erinaceus derived polysaccharides are mediated by intestinal immunology. Food \& Function. 2017; 8:10207. https://doi.org/10.1039/c7fo00071e.

35. Lu CC, Huang WS, Lee KF, Lee KC, Hsieh MC, Huang CY, Lee LY, Lee BO, Teng CC, Shen CH, Tung SY, Kuo HC. Inhibitory effect of Erinacines A on the growth of DLD-1 colorectal cancer cells is induced by generation of reactive oxygen species and activation of p70S6K and p21. Journal of Functional Foods. 2016; 21:474-84. https://doi. org/10.1016/j.jff.2015.12.031.

36. Kuo HC, Kuo YR, Lee KF, Hsieh MC, Huang CY, Hsieh YY, Lee KC, Kuo HL, Lee LY, Chen WP, Chen CC, Tung SY. A Comparative Proteomic Analysis of Erinacine A's Inhibition of Gastric Cancer Cell Viability and Invasiveness. Cell Physiol Biochem. 2017; 43:195-208. https://doi. org/10.1159/000480338.
37. Lee KC, Kuo HC, Shen CH, Lu CC, Huang WS, Hsieh MC, Huang CY, Kuo YH, Hsieh YY, Teng CC, Lee LY, Tung SY. A proteomics approach to identifying novel protein targets involved in erinacine A-mediated inhibition of colorectal cancer cells' aggressiveness. J Cell Mol Med. 2017; 21:58899. https://doi.org/10.1111/jcmm.13004.

38. Lee SR, Jung K, Noh HJ, Park YJ, Lee HL, Lee KR, Kang $\mathrm{KS}$, Kim KH. A new cerebroside from the fruiting bodies of Hericium erinaceus and its applicability to cancer treatment. Bioorganic \& Medicinal Chemistry Letters. 2015; 25:57125. https://doi.org/10.1016/j.bmcl.2015.10.092.

39. Diling C, Chaoqun Z, Jian Y, Jian L, Jiyan S, Yizhen X, Guoxiao L. Immunomodulatory Activities of a Fungal Protein Extracted from Hericium erinaceus through Regulating the Gut Microbiota. Front Immunol. 2017; 8:666. https://doi.org/10.3389/fimmu.2017.00666.

40. Zan X, Cui F, Li Y, Yang Y, Wu D, Sun W, Ping L. Hericium erinaceus polysaccharide-protein HEG-5 inhibits SGC-7901 cell growth via cell cycle arrest and apoptosis. Int J Biol Macromol. 2015; 76:242-53. https://doi.org/10.1016/j. ijbiomac.2015.01.060.

41. Jia LM, Liu L, Dong Q, Fang JN. Structural investigation of a novel rhamnoglucogalactan isolated from the fruiting bodies of the fungus Hericium erinaceus. Carbohydr Res. 2004; 339:2667-71. https://doi.org/10.1016/j. carres.2004.07.027.

42. Wong JY, Abdulla MA, Raman J, Phan CW, Kuppusamy UR, Golbabapour S, Sabaratnam V. Gastroprotective Effects of Lion's Mane Mushroom Hericium erinaceus (Bull.:Fr.) Pers. (Aphyllophoromycetideae) Extract against Ethanol-Induced Ulcer in Rats. Evid Based Complement Alternat Med. 2013; 2013:492976. https://doi. org/10.1155/2013/492976.

43. Liu JH, Li L, Shang XD, Zhang JL, Tan Q. Anti-Helicobacter pylori activity of bioactive components isolated from Hericium erinaceus. Journal of Ethnopharmacology. 2016; 183:54-8. https://doi.org/10.1016/j.jep.2015.09.004.

44. Wang MX, Gao Y, Xu DD, Gao QP. A polysaccharide from cultured mycelium of Hericium erinaceus and its antichronic atrophic gastritis activity. International Journal of Biological Macromolecules. 2015; 81:656-61. https://doi. org/10.1016/j.ijbiomac.2015.08.043.

45. Wang M, Kanako N, Zhang Y, Xiao X, Gao Q, Tetsuya K. A unique polysaccharide purified from Hericium erinaceus mycelium prevents oxidative stress induced by $\mathrm{H} 2 \mathrm{O} 2$ in human gastric mucosa epithelium cell. PLoS One. 2017; 12:e0181546. https://doi.org/10.1371/journal. pone. 0181546 .

46. Wolters N, Schembecker G, Merz J. Erinacine C: A novel approach to produce the secondary metabolite by submerged cultivation of Hericium erinaceus. Fungal Biology. 2015; 119:1334-44. https://doi.org/10.1016/j.funbio.2015.10.005.

47. Kim YO, Park HW, Kim JH, Lee JY, Moon SH, Shin CS. Anti-cancer effect and structural characterization of endo-polysaccharide from cultivated mycelia of 
Inonotus obliquus. Life Sci. 2006; 79:72-80. https://doi. org/10.1016/j.lfs.2005.12.047.

48. Taji S, Yamada T, Wada S, Tokuda H, Sakuma K, Tanaka R. Lanostane-type triterpenoids from the sclerotia of Inonotus obliquus possessing anti-tumor promoting activity. Eur J Med Chem. 2008; 43:2373-9. https://doi.org/10.1016/j. ejmech.2008.01.037.

49. Zheng W, Zhang M, Zhao Y, Wang Y, Miao K, Wei Z. Accumulation of antioxidant phenolic constituents in submerged cultures of Inonotus obliquus. Bioresour Technol. 2009; 100:1327-35. https://doi.org/10.1016/j. biortech.2008.05.002.

50. Handa N, Yamada T, Tanaka R. An unusual lanostane-type triterpenoid, spiroinonotsuoxodiol, and other triterpenoids from Inonotus obliquus. Phytochemistry. 2010; 71:1774-9. https://doi.org/10.1016/j.phytochem.2010.07.005.

51. Burczyk J, Gawron A, Slotwinska M, Smietana B, Terminska K. Antimitotic activity of aqueous extracts of Inonotus obliquus. Boll Chim Farm. 1996; 135:306-9.

52. Tsai CC, Li YS, Lin PP. Inonotus obliquus extract induces apoptosis in the human colorectal carcinoma's HCT-116 cell line. Biomed Pharmacother. 2017; 96:1119-26. https://doi. org/10.1016/j.biopha.2017.11.111.

53. Lee SH, Hwang HS, Yun JW. Antitumor Activity of Water Extract of a Mushroom, Inonotus obliquus, against HT-29 Human Colon Cancer Cells. Phytotherapy Research. 2009; 23:1784-9. https://doi.org/10.1002/ptr.2836.

54. Youn MJ, Kim JK, Park SY, Kim Y, Kim SJ, Lee JS, Chai KY, Kim HJ, Cui MX, So HS, Kim KY, Park R. Chaga mushroom (Inonotus obliquus) induces G0/G1 arrest and apoptosis in human hepatoma HepG2 cells. World J Gastroenterol. 2008; 14:511-7.

55. Youn MJ, Kim JK, Park SY, Kim Y, Park C, Kim ES, Park KI, So HS, Park R. Potential anticancer properties of the water extract of Inonotus [corrected] obliquus by induction of apoptosis in melanoma B16-F10 cells. J Ethnopharmacol. 2009; 121:221-8. https://doi.org/10.1016/j.jep.2008.10.016.

56. Chung MJ, Chung CK, Jeong Y, Ham SS. Anticancer activity of subfractions containing pure compounds of Chaga mushroom (Inonotus obliquus) extract in human cancer cells and in Balbc/c mice bearing Sarcoma-180 cells. Nutr Res Pract. 2010; 4:177-82. https://doi.org/10.4162/ nrp.2010.4.3.177.

57. Nakata T, Yamada T, Taji S, Ohishi H, Wada S, Tokuda H, Sakuma K, Tanaka R. Structure determination of inonotsuoxides $\mathrm{A}$ and $\mathrm{B}$ and in vivo anti-tumor promoting activity of inotodiol from the sclerotia of Inonotus obliquus. Bioorganic \& Medicinal Chemistry. 2007; 15:257-64. https://doi.org/10.1016/j.bmc.2006.09.064.

58. Nomura M, Takahashi T, Uesugi A, Tanaka R, Kobayashi S. Inotodiol, a Lanostane Triterpenoid, from Inonotus obliquus Inhibits Cell Proliferation through Caspase-3-dependent Apoptosis. Anticancer Research. 2008; 28:2691-6.
59. Kuriyama I, Nakajima Y, Nishida H, Konishi T, Takeuchi T, Sugawara F, Yoshida H, Mizushina Y. Inhibitory effects of low molecular weight polyphenolics from Inonotus obliquus on human DNA topoisomerase activity and cancer cell proliferation. Molecular Medicine Reports. 2013; 8:535-42. https://doi.org/10.3892/mmr.2013.1547.

60. Sung B, Pandey MK, Nakajima Y, Nishida H, Konishi T, Chaturvedi MM, Aggarwal BB. Identification of a novel blocker of IkappaBalpha kinase activation that enhances apoptosis and inhibits proliferation and invasion by suppressing nuclear factor-kappaB. Mol Cancer Ther. 2008; 7:191-201. https://doi.org/10.1158/1535-7163. MCT-07-0406.

61. Kim YO, Han SB, Lee HW, Ahn HJ, Yoon YD, Jung JK, Kim HM, Shin CS. Immuno-stimulating effect of the endo-polysaccharide produced by submerged culture of Inonotus obliquus. Life Sci. 2005; 77:2438-56. https://doi. org/10.1016/j.1fs.2005.02.023.

62. Fan LP, Ding SD, Ai LZ, Deng KQ. Antitumor and immunomodulatory activity of water-soluble polysaccharide from Inonotus obliquus. Carbohydrate Polymers. 2012; 90:870-4. https://doi.org/10.1016/j.carbpol.2012.06.013.

63. Won DP, Lee JS, Kwon DS, Lee KE, Shin WC, Hong EK. Immunostimulating activity by polysaccharides isolated from fruiting body of Inonotus obliquus. Molecules and Cells. 2011; 31:165-73. https://doi.org/10.1007/ s10059-011-0022-x.

64. Lee KR, Lee JS, Song JE, Ha SJ, Hong EK. Inonotus obliquus-derived polysaccharide inhibits the migration and invasion of human non-small cell lung carcinoma cells via suppression of MMP-2 and MMP-9. Int J Oncol. 2014; 45:2533-40. https://doi.org/10.3892/ijo.2014.2685.

65. Lee KR, Lee JS, Kim YR, Song IG, Hong EK. Polysaccharide from Inonotus obliquus inhibits migration and invasion in B16-F10 cells by suppressing MMP-2 and MMP-9 via downregulation of NF-kappaB signaling pathway. Oncol Rep. 2014; 31:2447-53. https://doi. org/10.3892/or.2014.3103.

66. Kang JH, Jang JE, Mishra SK, Lee HJ, Nho CW, Shin D, Jin M, Kim MK, Choi C, Oh SH. Ergosterol peroxide from Chaga mushroom (Inonotus obliquus) exhibits anti-cancer activity by down-regulation of the beta-catenin pathway in colorectal cancer. J Ethnopharmacol. 2015; 173:303-12. https://doi.org/10.1016/j.jep.2015.07.030.

67. Blagodatski A, Poteryaev D, Katanaev VL. Targeting the Wnt pathways for therapies. Mol Cell Ther. 2014; 2:28. https://doi.org/10.1186/2052-8426-2-28.

68. Zhang X, Bao C, Zhang J. Inotodiol suppresses proliferation of breast cancer in rat model of type 2 diabetes mellitus via downregulation of beta-catenin signaling. Biomed Pharmacother. 2018; 99:142-50. https://doi.org/10.1016/j. biopha.2017.12.084.

69. Gery A, Dubreule C, Andre V, Rioult JP, Bouchart V, Heutte N, Eldin de Pecoulas P, Krivomaz T, Garon D. Chaga (Inonotus obliquus), a Future Potential Medicinal Fungus 
in Oncology? A Chemical Study and a Comparison of the Cytotoxicity Against Human Lung Adenocarcinoma Cells (A549) and Human Bronchial Epithelial Cells (BEAS-2B). Integr Cancer Ther. 2018. 1534735418757912. https://doi. org/10.1177/1534735418757912.

70. Kuan YC, Wu YJ, Hung CL, Sheu F. Trametes versicolor Protein YZP Activates Regulatory B Lymphocytes - Gene Identification through De Novo Assembly and Function Analysis in a Murine Acute Colitis Model. Plos One. 2013; 8:e72422. https://doi.org/10.1371/journal.pone.0072422.

71. Standish LJ, Wenner CA, Sweet ES, Bridge C, Nelson A, Martzen M, Novack J, Torkelson C. Trametes versicolor mushroom immune therapy in breast cancer. J Soc Integr Oncol. 2008; 6:122-8.

72. Zhou XW, Jiang H, Lin J, Tang KX. Cytotoxic activities of Coriolus versicolor (Yunzhi) extracts on human liver cancer and breast cancer cell line. African Journal of Biotechnology. 2007; 6:1740-3.

73. Lau CBS, Ho CY, Kim CF, Leung KN, Fung KP, Tse TF, Chan HHL, Chow MSS. Cytotoxic activities of Coriolus versicolor (Yunzhi) extract on human leukemia and lymphoma cells by induction of apoptosis. Life Sciences. 2004; 75:797-808. https://doi.org/10.1016/j.lfs.2004.04.001.

74. Hsieh TC, Wu JM. Cell growth and gene modulatory activities of Yunzhi (Windsor Wunxi) from mushroom Trametes versicolor in androgen-dependent and androgeninsensitive human prostate cancer cells. Int J Oncol. 2001; 18:81-8.

75. Awadasseid A, Hou J, Gamallat Y, Xueqi S, Eugene KD, Musa Hago A, Bamba D, Meyiah A, Gift C, Xin Y. Purification, characterization, and antitumor activity of a novel glucan from the fruiting bodies of Coriolus Versicolor. PLoS One. 2017; 12:e0171270. https://doi.org/10.1371/ journal.pone.0171270.

76. Cui T, Chisti Y. Polysaccharopeptides of Coriolus versicolor: physiological activity, uses, and production. Biotechnology Advances. 2003; 21:109-22. https://doi. org/10.1016/S0734-9750(03)00002-8.

77. Fisher M, Yang LX. Anticancer effects and mechanisms of polysaccharide-K (PSK): Implications of cancer immunotherapy. Anticancer Research. 2002; 22:1737-54.

78. Chang Y, Zhang M, Jiang Y, Liu Y, Luo H, Hao C, Zeng $\mathrm{P}$, Zhang L. Preclinical and clinical studies of Coriolus versicolor polysaccharopeptide as an immunotherapeutic in China. Discov Med. 2017; 23:207-19.

79. Wang J, Dong B, Tan Y, Yu S, Bao YX. A study on the immunomodulation of polysaccharopeptide through the TLR4-TIRAP/MAL-MyD88 signaling pathway in PBMCs from breast cancer patients. Immunopharmacology and Immunotoxicology. 2013; 35:497-504. https://doi.org/10.3 109/08923973.2013.805764.

80. Sekhon BK, Sze DMY, Chan WK, Fan K, Li GQ, Moore DE, Roubin RH. PSP activates monocytes in resting human peripheral blood mononuclear cells:
Immunomodulatory implications for cancer treatment. Food Chemistry. 2013; 138:2201-9. https://doi.org/10.1016/j. foodchem.2012.11.009.

81. Sekhon BK, Roubin RH, Li YM, Devi PB, Nammi S, Fan K, Sze DMY. Evaluation of Selected Immunomodulatory Glycoproteins as an Adjunct to Cancer Immunotherapy. Plos One. 2016; 11: e0146881. https://dx.doi.org/10.1371/ journal.pone.0146881.

82. Engel AL, Sun GC, Gad E, Rastetter LR, Strobe K, Yang Y, Dang YS, Disis ML, Lu HL. Protein-bound polysaccharide activates dendritic cells and enhances OVA-specific T cell response as vaccine adjuvant. Immunobiology. 2013; 218:1468-76. https://doi.org/10.1016/j.imbio.2013.05.001.

83. Lu H, Yang Y, Gad E, Wenner CA, Chang A, Larson ER, Dang Y, Martzen M, Standish LJ, Disis ML. Polysaccharide krestin is a novel TLR2 agonist that mediates inhibition of tumor growth via stimulation of CD8 T cells and NK cells. Clin Cancer Res. 2011; 17:67-76. https://doi. org/10.1158/1078-0432.CCR-10-1763.

84. Lu H, Yang Y, Gad E, Inatsuka C, Wenner CA, Disis ML, Standish LJ. TLR2 agonist PSK activates human NK cells and enhances the antitumor effect of HER2targeted monoclonal antibody therapy. Clin Cancer Res. 2011; 17:6742-53. https://doi.org/10.1158/1078-0432. CCR-11-1142.

85. Price LA, Wenner CA, Sloper DT, Slaton JW, Novack JP. Role for toll-like receptor 4 in TNF-alpha secretion by murine macrophages in response to polysaccharide Krestin, a Trametes versicolor mushroom extract. Fitoterapia. 2010; 81:914-9. https://doi.org/10.1016/j.fitote.2010.06.002.

86. Torkelson CJ, Sweet E, Martzen MR, Sasagawa M, Wenner CA, Gay J, Putiri A, Standish LJ. Phase 1 Clinical Trial of Trametes versicolor in Women with Breast Cancer. ISRN Oncol. 2012; 2012:251632. https://doi. org/10.5402/2012/251632.

87. Quayle K, Coy C, Standish L, Lu H. The TLR2 agonist in polysaccharide- $\mathrm{K}$ is a structurally distinct lipid which acts synergistically with the protein-bound beta-glucan. J Nat Med. 2015; 69:198-208. https://doi.org/10.1007/ s11418-014-0879-z.

88. Yamasaki A, Onishi H, Imaizumi A, Kawamoto M, Fujimura A, Oyama Y, Katano M. Protein-bound Polysaccharide-K Inhibits Hedgehog Signaling Through Down-regulation of MAML3 and RBPJ Transcription Under Hypoxia, Suppressing the Malignant Phenotype in Pancreatic Cancer. Anticancer Res. 2016; 36:3945-52.

89. Xin M, Ji X, De La Cruz LK, Thareja S, Wang B. Strategies to target the hedgehog signaling pathway for cancer therapy. Med Res Rev. 2018; 38:870-913. https://doi.org/10.1002/ med.21482.

90. Namikawa T, Fukudome I, Ogawa M, Munekage E, Munekage M, Shiga M, Maeda H, Kitagawa H, Kobayashi M, Hanazaki K. Clinical efficacy of protein-bound polysaccharide $\mathrm{K}$ in patients with gastric cancer undergoing chemotherapy with an oral fluoropyrimidine (S-1). Eur J 
Surg Oncol. 2015. 41:795-800. https://doi.org/10.1016/j. ejso.2015.02.012.

91. Fritz H, Kennedy DA, Ishii M, Fergusson D, Fernandes R, Cooley K, Seely D. Polysaccharide K and Coriolus versicolor Extracts for Lung Cancer: A Systematic Review. Integrative Cancer Therapies. 2015; 14:201-11. https://doi. org/10.1177/1534735415572883.

92. Jiang JH, Thyagarajan-Sahu A, Loganathan J, Eliaz I, Terry C, Sandusky GE, Sliva D. BreastDefend (TM) prevents breast-to-lung cancer metastases in an orthotopic animal model of triple-negative human breast cancer. Oncology Reports. 2012; 28:1139-45. https://doi.org/10.3892/ or.2012.1936.
93. Stamets P. Trametes versicolor (Turkey Tail Mushrooms) and the Treatment of Breast Cancer. Glob Adv Health Med. 2012; 1:20. https://doi.org/10.7453/gahmj.2012.1.5.007.

94. Standish LJ, Dowd F, Sweet E, Dale L, Weaver M, Osborne $\mathrm{B}$, Andersen MR. Breast Cancer Integrative Oncology Care and Its Costs. Integr Cancer Ther. 2017; 16:85-95. https:// doi.org/10.1177/1534735416649034.

95. Guggenheim AG, Wright KM, Zwickey HL. Immune Modulation From Five Major Mushrooms: Application to Integrative Oncology. Integr Med (Encinitas). 2014; $13: 32-44$.

96. Jiang J, Sliva D. Novel medicinal mushroom blend suppresses growth and invasiveness of human breast cancer cells. Int J Oncol. 2010; 37:1529-36. 